\title{
Response to Fertilization of Strip-cultivated Plantains Growing on a Steep Latosol in the Humid Mountain Region of Puerto Rico'
}

\author{
Rubén Caro-Costas, Fernando Abruña, and José Vicente-Chandler ${ }^{2}$
}

\section{INTRODUCTION}

Plantains (Musa paradisiaca), a staple in the Puerto Rican diet, are generally grown on steep mountain lands where erosion is a serious problem. Vicente-Chandler and Figarella ${ }^{3}$ have developed a method for producing high yields of plantains with proper conservation on steep lands by planting directly in the sod followed by strip cultivation. In these experiments, strip-cultivated plantains growing on a Catalina clay responded strongly to applications of 200 pounds per acre of nitrogen and of phosphoric acid, but did not respond to applications of limestone, magnesium or potassium.

The experiment described in this paper was aimed at determining the effects of fertilization with nitrogen, phosphorus, potassium, and magnesium on yields and foliar composition of strip-cultivated plantains growing on a steep Cialitos clay, the most extensive Latosol of the Humid Mountain Region of Puerto Rico.

\section{MATERIALS AND METHODS}

The experiment was carried out at Orocovis where the mean annual temperature is about $75^{\circ} \mathrm{F}$., with seasonal variations of about $10^{\circ} \mathrm{F}$. Rainfall, averaging about 65 inches annually, is fairly well-distributed throughout the year.

Cialitos clay is a deep latosol with primarily kaolinitic clay minerals and a high free iron oxide content. The surface 6 inches of soil at the experimental site has the following characteristics:

1 This paper covers work carried out cooperatively between the Soil and Water Conservation Research Division, Agricultural Research Service, USDA, and the Agricultural Experiment Station of the University of Puerto Rico.

2 Agronomist, cooperative between the Agricultural Experiment Station of the University of Puerto Rico and the U.S. Department of Agriculture, and Soil Scientists, Soil and Water Conservation Research Division, Agricultural Research Service, USDA, respectively, stationed at Río Piedras, P.R.

\& Vicente-Chandler, J., and Figarella, J., Experiments on Plantain Production with Conservation in the Mountain Region of Puerto Rico, J. Agr. Univ. P.R. 46(3) 226-36, 1962. 


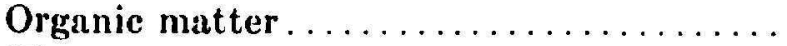

Nitrogen . . . . . . . . . . . . . . . . .

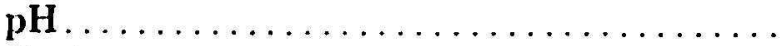

Exchange capacity .................

Exchangeable calcium. ...............

Exchangeable potassium ..............

Exchangeable magnesium ...............

Dilute acid-soluble phosphorus . . . . . . . .

Volume weight

Pores drained at $1 / 3$ atmosphere tension...

$\begin{array}{cr}\text { pereent } & 4.0 \\ \text { do. } & .2 \\ & 4.9 \\ \text { meq. } / 100 \mathrm{gm} . \text { of soil } & 14.5 \\ \text { do. } & 3.4 \\ \text { lb. } / \mathrm{A} . & 180 \\ \text { do. } & 110 \\ \text { do. } & <20\end{array}$

percent
4.0

.2

4.9

4.5

3.4

180

$<20$

11

Plantains were planted 5 feet apart in rows 15 feet apart. Plots consisted of six trees in a row and were surrounded by ditches to prevent cross-feeding and to keep fertilizer from washing into adjoining plots. An 8-foot-wide strip of grass, subdued by periodic applications of a contact herbicide, was maintained between rows to control erosion. Growth of weeds in the rows was prevented by an application of 2-chloro-4,6-bis-(ethylamine)-i)-triazene (Simazine) at the rate of 3 pounds per acre, applied immediately after planting and repeated 4 months later.

Fertilizer treatments, shown in detail in table 1, consisted of three levels each of nitrogen and phosphorus, and two of potassium and magnesium, each varied in the presence of a high level of the other nutrients. All treatments were replicated six times in a randomized block design. Three tons of limestone per acre were applied to all plots at planting, half in the planting hole and the remainder distributed in the rows. All the phosphorus, as 20-percent superphosphate, was applied in the planting holes. Nitrogen, as ammonium sulfate, and potassium, as potassium chloride, were distributed under the leaf canopy in three equal applications 1,5 , and 9 months after planting. Magnesium, as magnesium sulfate, was applied in one application 1 month after planting.

Corms of the Maricongo plantain variety used as seed were cleaned and immersed in boiling water for 1 minute to kill nematodes, and in aldrin solution to kill stemborers. The planting holes and surrounding soil were sprayed with aldrin solution before planting. The trees were sprayed about every 3 weeks with oil, starting at 6 months, to control leaf spot.

Harvesting started in January 1963, 15 months after planting, and continued through April. Trees not bearing a bunch at this time were considered as nonbearing, since they were small and gave evidence of producing little or no fruit and certainly none of commercial size. All bunches were weighed and number of fruits determined.

A strip from the central section of the lamina of the third oldest leaf of the middle four trees of each plot was taken 7 months after planting, dried, and analyzed for nitrogen, phosphorus, calcium, potassium, magnesium, and manganese. 


\section{RESUL'TS}

Plantains responded strongly in yield (table 1) to applications of all nutrients tested, i.e., nitrogen, phosphorus, potassium, and magnesium, when all other nutrients were present in abundance. Yield response to fertilization generally resulted from the production of larger bunches of fruit and from an increase in the number of bearing trees (table 1). Size of the individual fruit, averaging about $\mathbf{0 . 6}$ pound, was not significantly affected by fertilization.

Yields of plantains were increased by 67.7 percent, from 11,020 to 18,480 pounds of fruit per acre, by the application of 200 pounds of nitrogen per

T.1вІ.E 1.-Elfect of ferlilization on yields of intensively managed plantains growing on a lypical latosol (('ialitos clay) in the Humid Mountain Region of Puerlo Rico

\begin{tabular}{|c|c|c|c|c|c|c|c|c|c|c|}
\hline \multirow{2}{*}{$\begin{array}{l}\text { Treat- } \\
\text { ment } \\
\text { Pio. }\end{array}$} & \multicolumn{4}{|c|}{ Fertilization (per acre) } & \multirow{2}{*}{\multicolumn{2}{|c|}{ Fruits per acre }} & \multirow{2}{*}{$\begin{array}{l}\text { Average } \\
\text { weight } \\
\text { of bunch }\end{array}$} & \multirow{2}{*}{$\begin{array}{l}\text { Average } \\
\text { fruits } \\
\text { per bunch }\end{array}$} & \multirow{2}{*}{$\begin{array}{c}\text { Average } \\
\text { weight per } \\
\text { fruit }\end{array}$} & \multirow{2}{*}{\begin{tabular}{|} 
Trees \\
bearing \\
a cron
\end{tabular}} \\
\hline & $x$ & $\mathrm{PaO}_{6}$ & $\mathrm{~K}$ & $\mathbf{M g}$ & & & & & & \\
\hline & $L b$. & $L b$. & $L b$. & $L b$. & $L b$. & Number & $L b$. & Number & $L b$. & Percent \\
\hline 1 & 200 & 200 & 400 & 100 & 18,480 & 29,830 & 24.4 & 40 & 0.61 & 94 \\
\hline 2 & 0 & 200 & 400 & 100 & 11,020 & 18,240 & 20.6 & 34 & .61 & 64 \\
\hline 3 & 400 & 200 & 400 & 100 & 16,390 & 29, (il:0 0 & 26.8 & 49 & .55 & 75 \\
\hline 4 & 200 & 0 & 400 & 100 & 7,700 & $13,61: 0$ & 19.0 & 34 & $.56 j$ & 47 \\
\hline 5 & 200 & 400 & 400 & 100 & 15,820 & $26,-100$ & 24.7 & +1 & . 10 & 81 \\
\hline ; & 200 & 200 & 0 & 100 & 12,580 & 22,290 & 20.7 & 39 & .54 & 75 \\
\hline 7 & 200 & 200 & 400 & 0 & 9,680 & $15,+40$ & 20.9 & 34 & .61 & 55 \\
\hline & \multirow{2}{*}{\multicolumn{3}{|c|}{ I.ti.l. }} & 0.05 & & $9,3 \cdot 10$ & 3. & 5. & N.: & 28 \\
\hline & & & & .01 & 7,100 & 12,515 & 4.3 & 7.7 & N.S. & 38 \\
\hline
\end{tabular}

acre (treatment 2 vs. 1). The application of an additional 200 pounds of nitrogen did not further increase yields.

Yields were increased by 140 pereent, from 7,700 to 18,480 pounds of fruit per acre, by the application of 200 pounds of $\mathrm{P}_{2} \mathrm{O}_{5}$ per acre (treatment $4 \mathrm{rs}$. 1). The application of an additional 200 pounds of $\mathrm{P}_{2} \mathrm{O}_{5}$ did not further increase yields.

Yields of plantains were increased by 46.9 percent, from 12,580 to 18,480 pounds of fruit per acre, by the application of 400 pounds of potassium per acre (treatment is is. 1).

Yiclds of plantains were increased by 90.9 pereent, from 9,680 to 18,480 pounds of fruit per acre, by the application of 100 pounds of magnesium per acre (treatment 7 vs. 1). Plantains receiving no magnesium exhibited typical deficiency symptoms, including yellowing of the older leaves and reduced growth (fig. 1).

l.eaf-nutrient contents were increased by fertilization with the respective 
nutrients (table 2). Leaf composition at 7 months (table 2) when all the phosphorus and magnesium, and two-thirds of the nitrogen and potassium had been applied, clearly presaged the strong response in yields of plantains to this fertilization. Table 3 shows leaf contents of the various nutrients

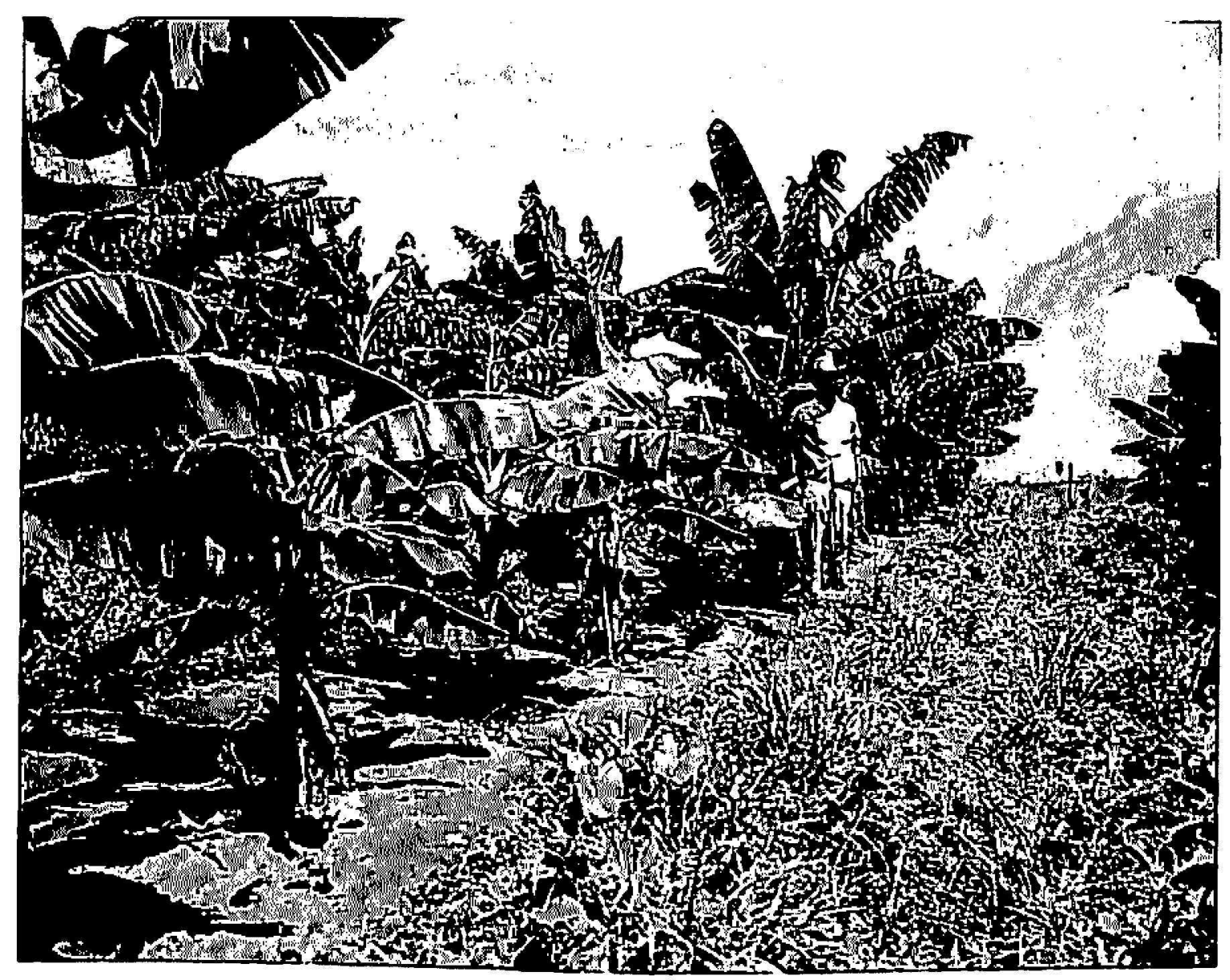

Fir. 1.-Response of strip-cultivated plantains to magnesium fertilization 9 mont hs af:er planting. Plants in foreground received no magnesium while those in the background received 100 pounds of magnesium per acre. Both plots were limed and heavily fertilized with nitrogen, phosphorus, and pot assium. Note absence of weeds in rows resulting from application of a herbicide and protection against erosion provided by contour strips of grass between rows.

associated with production of low and of high yields of plantains when all other nutrients were provided in abundance.

However, a high leaf content of a given nutrient is not indicative of high yields if another nutrient is deficient. For example, although nitrogen content of leaves from the no-phosphorus treatment-4 and no-magnesium treatment-7 plots was high, (table 2), yields were very low (table 1). Similarly, although the potassium content of leaves in the no-nitrogen treatment-2 and no-magnesium treatment-7 plots was high, very low yields were produced. It is obvious that, in order correctly to evaluate the nutritional 
status of plantains, it is necessary to have as complete a picture as possible of the nutrient content of the leaves.

The manganese content of the plantain leaves increased from 1,09 i to 1,745 p.p.m. as a result of heavy nitrogen fertilization (treatments 2 vs. 3). This may be explained by increased availability of soil manganese resulting from increased soil acidity, following heavy applications of ammonium

TABLE 2.-Dry-weight composition of plantain leaves 7 months after planting, as affected by fertilization with nitrogen, phosphorus, potassium, and magnesium

\begin{tabular}{|c|c|c|c|c|c|c|c|c|c|c|}
\hline \multirow{2}{*}{$\begin{array}{l}\text { Treat- } \\
\text { ment } \\
\text { No. }\end{array}$} & \multicolumn{4}{|c|}{ Fertilization (per acre) } & \multirow{2}{*}{ Nitrogen } & \multirow{2}{*}{$\begin{array}{l}\text { Phos- } \\
\text { phorus }\end{array}$} & \multirow{2}{*}{ Potassium } & \multirow{2}{*}{$\underset{\text { ium }}{\text { Magnes- }}$} & \multirow{2}{*}{ Calcium } & \multirow{2}{*}{ Manganes } \\
\hline & $\mathrm{N}$ & $\mathrm{P}_{2} \mathrm{O}_{5}$ & $\mathrm{~K}$ & $\mathrm{Mg}$ & & & & & & \\
\hline & $L b$. & $L b$. & $L b$. & Lb. & Percent & Pcrcent & Percent & Percent & Percent & p.p.m. \\
\hline 1 & 200 & 200 & 400 & 100 & 3.97 & 0.21 & 3.27 & 0.31 & 0.56 & 1,355 \\
\hline 2 & 0 & 200 & 400 & 100 & $3.4 ;$ & .22 & 3.53 & .36 & . (33 & 1,095 \\
\hline 3 & 400 & 200 & 400 & 100 & 4.22 & .21 & 3.06 & .30 & . 10 & $1,7+5$ \\
\hline 4 & 200 & 0 & 400 & 100 & 4.43 & .15 & 2.55 & .29 & .61 & 1,375 \\
\hline 5 & 200 & 400 & 400 & 100 & 3.97 & .22 & 3.51 & .30 & .63 & 1,325 \\
\hline (6 & 200 & 200 & 0 & 100 & 4.33 & .21 & 2.30 & .38 & .66 & 1,075 \\
\hline 7 & 200 & 200 & 400 & 0 & 4.14 & .23 & 3.49 & .15 & .70 & 1,475 \\
\hline \multicolumn{4}{|c|}{ L.S.I). } & $\begin{array}{l}0.05 \\
0.01\end{array}$ & $\begin{array}{r}0.26 \\
.35\end{array}$ & $\begin{array}{r}0.02 \\
.03\end{array}$ & $\begin{array}{r}0.34 \\
.45\end{array}$ & $\begin{array}{r}0.08 \\
.11\end{array}$ & $\begin{array}{l}\text { N.S. } \\
\text { N.S. }\end{array}$ & $\begin{array}{l}3164 \\
487\end{array}$ \\
\hline
\end{tabular}

TABLE 3.-Percenlages of leaf content of nutrients associated with high or low yields of plantains

\begin{tabular}{c|c|c}
\hline Nutrient & Low yields & High yields \\
\hline $\mathrm{N}$ & $3.40 \mathrm{j}$ & 3.97 \\
$\mathrm{P}$ & .15 & .21 \\
$\mathrm{~K}$ & 2.30 & 3.27 \\
$\mathrm{Mg}$ & .15 & .31 \\
\hline
\end{tabular}

sulfate. There was also strong evidence of an increase in manganese content following applications of potassium chloride (treatments 6 i's. 1). The manganese content of the plantain leaves was high in all cases and may have approached toxic levels. The increase in potassium content of the leaves from 2.i5) to 3.51 percent with increased phosphorus fertilization is also noteworthy.

The data presented indicate that, under the conditions of this experiment, plantains growing on soils having as much as 180 pounds per acre of exchangeable potassium, 110 pounds of exchangeable magnesium, and 0.2 percent of nitrogen will respond strongly to applications of these nutrients. 
It can be concluded that up to 200 pounds of nitrogen, 200 of phosphoric acid, 400 of potassium, and 100 of magnesium may be applied to intensively managed, strip-cultivated plantains growing on latosols in the Humid Mountain Region of Puerto Rico. The magnitude of the increase in yields resulting from such applications of fertilizer and the high value of the crop (average farm price $=4 \notin$ per pound) leave no doubt as to the economic feasibility of fertilizing this heavily.

\section{SUMMARY}

The effects of nitrogen, phosphorus, potassium, and magnesium fertilization on yields and foliar composition of strip-cultivated plantains growing on steep Cialitos clay, a typical latosol of the Humid Mountain Region of Puerto Rico, were determined.

Yields of plantains were sharply increased by the application of either 200 pounds of nitrogen, 200 of phosphoric acid, 400 of potassium, or 100 pounds of magnesium per acre, when all other nutrients were present in abundance.

Foliar composition of the plantains at 7 months presaged their yield response to the various nutrients. Approximate percentage leaf contents indicating a deficiency and a sufficiency, respectively, of the various nutrients when all other nutrients were provided in abundance were as follows: Nitrogen 3.5 and 4.0 , phosphorus 0.15 and 0.21 , potassium 2.3 and 3.3 percent, and magnesium 0.15 and 0.31 .

\section{RESUMEN}

Se estudió el efecto de las aplicaciones de nitrógeno, fósforo, potasio y magnesio sobre el rendimiento y la composición foliar de plátanos cultivados en franjas en un suelo Cialitos arcilloso que es un latosol típico de la región montañosa de Puerto Rico.

La producción de plátanos aumentó grandemente cuando se aplicaron 200 libras de nitrógeno, 200 libras de ácido fosfórico, 400 libras de potasio, o cuando se aplicaron 100 libras de magnesio por cuerda cuando había abundancia de los otros nutrimentos.

La composición foliar de los plátanos a los 7 meses ya señalaba cuál habría de ser el rendimiento con la aplicación de los distintos nutrimentos. Los porcentajes aproximados de los distintos nutrimentos en las hojas, señalando su deficiencia y suficiencia respectivamente, son como sigue: Nitrógeno 3.5 y 4.0 , fósforo 0.15 y 0.21 , potasio 2.3 y 3.3 , y magnesio 0.15 y 0.31 . 